\title{
Strategic analysis of inter-Andean food circuits: a combination of structural dimensions and measuring of socio-productive profiles
}

\author{
Carlos Moreno-Miranda ${ }^{1,2^{*}}$ \\ Jenny Gabriela Solís ${ }^{2}$ \\ Raúl Moreno 3 \\ Pablo Moreno ${ }^{4}$
}

\begin{abstract}
The fruit and vegetable sector in Ecuador has shown promising performance in domestic and international markets. However, this sector has faced problems of a social, economic and productive nature in its structure and articulations that require intervention. The case of the tree tomato agri-food network, located in the central Andean area of Ecuador, is part of this sector. This study shows its main social and productive characteristics, a horizontal and vertical dimensioning, and proposes strategies focused on improving their productive performance. In this study, a systemic methodology was applied aimed at the identification and characterization of stages, agents and activities (primary and support). Additionally, network governance mechanisms were analyzed. The study concluded that inclusion of women, the sense of associativity of processors and distributors, the training of producers in topics related to post-harvest and good agricultural practices would significantly improve the economic performance of the network and encourage greater participation of agents involved. Finally, it was deduced that the network requires increasing the area assigned to the tree tomato crop and the application of sustainable greenhouse production systems to increase yields.
\end{abstract}

Keywords: governance, tree tomato, network, socio-productive.

\section{Análisis estratégico de los circuitos alimentarios interandinos: una combinación de dimensiones estructurales y, medición de perfiles socioproductivos}

\begin{abstract}
Resumen
El sector de las frutas y hortalizas en Ecuador ha mostrado un desempeño prometedor en mercados de tipo doméstico e internacional. Asimismo, este sector ha enfrentado problemas de carácter social, económico y productivo en su estructura y articulaciones que hasta el momento requieren de intervención. El caso de la red agroalimentaria del tomate de árbol, situada en la zona andina central del país, es uno de tantos ejemplos del mencionado sector; en este sentido, el presente estudio muestra las principales características sociales y productivas, un dimensionamiento horizontal y vertical, y la propuesta de estrategias enfocadas en la mejora de su desempeño productivo. En el estudio se aplicó una metodología sistémica, encaminada a la identificación y caracterización de etapas, agentes y actividades (primarias y de soporte), y el análisis de los mecanismos de gobernanza de la red. El estudio concluyó, por una parte, en la inclusión de mujeres, el sentido de asociatividad de procesadores y distribuidores, y la formación de productores en temáticas relacionadas a poscosecha y buenas prácticas agrícolas, que mejorarían significativamente el desempeño económico de la red, y, por otro lado, incentivarían una mayor participación de los agentes involucrados. Finalmente, se dedujo que la red requiere aumentar el área asignada al cultivo de tomate de árbol y la aplicación de sistemas de producción bajo invernadero que incrementen los rendimientos.
\end{abstract}

Palabras clave: Gobernanza, tomate de árbol, red, socio-productivo.

\footnotetext{
'Wageningen University \& Research, Agricultural Economics and Rural Policy Department, Campus Hollandseweg 1, 6706 KN Wageningen, Wageningen -The Netherlands.

2Universidad Técnica de Ambato, Facultad de Ciencia e Ingeniería en Alimentos, Campus Huachi, Av. de Los Chasquis, Ambato-Ecuador. 3Universidad de Barcelona, Facultad de Ciencias de la Alimentación, Campus Diagonal, Av. de Joan XXIII, 27-31, Barcelona-España. ${ }^{4}$ Swansea University, School of Management, Bay Campus, Fabian Way, Swansea SA 1 8EN, Wales-United Kingdom.

*Corresponding author: carlos.morenomiranda@wur.nl
}

Received: January 4, 2019

Accepted: July 5, 2019 


\section{Introduction}

From 2005 to 2012, countries such as Peru, Chile, Mexico, Ecuador, Costa Rica and Colombia had a growing trend in fruit and vegetable production, resulting in a $4.2 \%$ annual increase in fruit and vegetable exports from these countries. This was also influenced by the 2011 event, where international metal and energy prices fell by an average of $10.5 \%$. This price behavior meant a slow recovery in developed economies and the slowdown of emerging economies, especially China, which became the main importer of raw materials and the first trading partner of Latin American countries (FAO, 2011; CEPAL, FAO, \& IICA, 2015). Parallel to the abovementioned international market events, the fruit and vegetable production chains of some countries, mainly in Central America, experienced heavy losses in their production stages and subsystems as a result of droughts, pests and diseases, as well as climatic conditions, making it difficult to produce significant volumes of raw materials that would enable them to face the international market, causing losses to some extent of the dynamism of agri-food exports in Latin America (FAO, 2011; ECLAC, FAO, \& IICA, 2015).

However, Latin American countries have comparative advantages in the agricultural sector, so their efforts must be consolidated in competitive advantages that incorporate technology and efficient management systems into their production processes (Orjuela, Castañeda, \& Calderón, 2008). In order to do so, it is necessary to compete on the basis of a Productive Network which is aimed at implementing associative structures (Zambrano, 2016), able to define strategies that provide comprehensive answers to the internal and external problems of the network, that would efficiently channel resources, generate added value and achieve the sustainable development of productive agents in the agri-food sector (Arras, Fierro, Jáquez, \& López, 2017) (Miranda, 2011; Scott, 2013).

The fruit and vegetable sector in Ecuador has shown an increase in its share of the country's agricultural GDP, contributing $16 \%$ without considering banana and potato production (FAO, 2010; Glas, Alvarado, León, \& Parra, 2015; MAGAP, 2015). Regarding agricultural holdings, the units of agricultural production are relatively small with

\section{Introducción}

Durante el periodo 2005-2012, países como Perú, Chile, México, Ecuador, Costa Rica y Colombia presentaron una tendencia creciente en la producción de frutas y vegetales, lo que resultó en un incremento anual del $4.2 \%$ en las exportaciones hortofrutícolas de los mencionados países; en este evento también influyó el acontecimiento de 2011, donde los precios internacionales de metales y energía se redujeron $10.5 \%$ en promedio; ese comportamiento de los precios significó una lenta recuperación de las economías desarrolladas, y la desaceleración de economías emergentes, sobre todo de China, quien se transformó en el principal importador de materias primas y en el primer socio comercial de países latinoamericanos (FAO, 2011; CEPAL, FAO, \& IICA, 2015). Paralelamente a los mencionados acontecimientos del mercado internacional, las cadenas productivas de frutas y vegetales de algunos países, principalmente centroamericanos, experimentaron fuertes pérdidas en sus etapas y subsistemas de producción como consecuencia de sequías, plagas y enfermedades, así como condiciones climáticas, dificultando la producción de volúmenes de materias primas significativas que permitiesen enfrentar el mercado internacional, ocasionando pérdidas en cierta medida del dinamismo de exportaciones agroalimentarias en América Latina (FAO, 2011; CEPAL, FAO, \& IICA, 2015).

Por otro lado, los países latinoamericanos presentan ventajas comparativas en el sector agropecuario, por lo tanto, sus esfuerzos deben consolidarse en ventajas competitivas que incorporen tecnología y sistemas de gestión eficientes a sus procesos productivos (Orjuela, Castañeda, \& Calderón, 2008). Para ello, es necesario competir en función de una Red Productiva, misma que va encaminada a implementar estructuras asociativas (Zambrano, 2016), capaces de definir estrategias que den respuestas integrales a los problemas del entorno interno y externo a la red, que canalicen eficientemente recursos, generen valor agregado y logren el desarrollo sostenible de los agentes productivos del sector agroalimentario (Arras, Fierro, Jáquez, \& López, 2017) (Miranda, 2011; Scott, 2013). 
areas less than 100 ha and with a high diversification of products. They are also characterized by their frequent impact on transactional costs (Blandon, Henson, \& Cranfield, 2009) due to the lack of planning in the supply and logistics of raw material transport which is evidence of the adversities faced by these production systems (Paez, 2018). In fruit production the holdings are large (areas larger than 100 ha), but with a lower degree of product diversification; these have more efficient coordination mechanisms in harvest logistics, classification and other procedures demanded by domestic and foreign markets (IFAD, 2011).

Fruit and vegetable production is a viable monetary alternative for family farming systems or smallholders, as is the case of farmers involved in the tree tomato production network in the inter-Andean region of Ecuador where this study is focused. The changes in structure that this network has undergone throughout the expansion of modern agricultural production units have improved its market performance (MAGAP, 2015); however, it still presents challenges that must be resolved, such as adaptation to domestic and foreign market dynamics, adoption of efficient socioproductive models, production chains that generate business synergies and the basis for agricultural development policies (Hirschman, 1958). In this regard, a dimensioning study of the structure of the tree tomato production network is necessary. This study should consider social and productive aspects of tree tomato, contribute with information to identify weaknesses in the network, and understand the mechanism that governs it and that will allow the establishment of integrative strategic solutions that will contribute to the welfare of its actors.

From 2015-2017 tree tomato cultivation increased $70 \%$ in the Ecuadorian Sierra Region, with the provinces of Imbabura, Tungurahua and Pichincha standing out. This growth was generated as a result of the agroclimatic conditions of this region, the agricultural planification established by the State, and the improvement of varieties and crop productivity led by the National Institute of Agricultural Research (MAG, 2017). The market opportunities that exotic products have in European,
El sector de frutas y hortalizas en el Ecuador ha mostrado un incremento en su participación tributando $16 \%$ al PIB agrícola del país, esto sin considerar la producción de papas y banano (FAO, 2010; Glas, Alvarado, León, \& Parra, 2015; MAGAP, 2015). En el caso de explotaciones vegetales, las unidades de producción son relativamente pequeñas, con superficies menores a las 100 ha y una alta diversificación de productos, asimismo, se caracterizan por incidir frecuentemente en costos transaccionales (Blandon, Henson, \& Cranfield, 2009) debido a la falta de planificación en la oferta y la logística de transporte de materias primas, lo que evidencia las adversidades que enfrentan estos sistemas de producción (Paez, 2018). En la producción de frutas, las explotaciones son grandes (superficies mayores a las $100 \mathrm{ha}$ ), pero con un menor grado de diversificación de productos; estas presentan mecanismos de coordinación más eficientes en la logística de cosecha, clasificación y otros procedimientos que demandan los mercados nacionales como extranjeros (IFAD, 2011).

La producción de frutas y hortalizas constituye una alternativa económica viable para los sistemas familiares campesinos de producción o minifundistas, como es el caso de agricultores involucrados en la red productiva del tomate de árbol de la zona interandina del Ecuador donde se centró este estudio. Los cambios en la estructura que ha experimentado la mencionada red a través de la expansión de modernas unidades de producción han significado una mejora en su desempeño de mercado (MAGAP, 2015). Pese a esto, aún presenta retos que deben ser resueltos, como la adaptación al dinamismo de mercados nacionales y extranjeros, adopción de modelos socio-productivos eficientes, encadenamientos productivos generadores de sinergias empresariales y la fundamentación de políticas agrarias de desarrollo (Hirschman, 1958). En este sentido, es necesario un estudio del dimensionamiento de la estructura de la red productiva del tomate de árbol, considerando aspectos sociales y productivos, que aporte con información para la identificación de debilidades a nivel de red, comprender el mecanismo que la gobierna y permita establecer soluciones 
North American and Asian markets are also determinant since they have motivated an increase in cultivated area for this crop (INIAP, 2016). On the contrary, there is an estimated production of 29725.0 tons of tree tomato per year, where $70.2 \%$ is used by agro-industries and exporting enterprises, while $29.8 \%$ is commercialized fresh locally and regionally. There is a constant demand for nontraditional crops in the global market, such as tree tomato, passion fruit, naranjilla, pineapple and goldenberry, which has encouraged production and exportation diversification in Ecuador (PROECUADOR, 2016).

Tree tomato occupies an important place in fruit exportation. It is considered an exotic fruit craved by many people, achieving high commercial value (Fernández, 2018). In addition, its nutritional characteristics make it more attractive for marketing and commercializing (SAE, 2017). Nevertheless, at a domestic level, this fruit is little consumed due to the lack of knowledge of its functional and nutritional benefits; however, pharmaceutical and biotechnology enterprises have shown its curative and preventive properties against prostatic, cardiovascular, digestive and carcinogenic diseases (Bojórquez, González, \& Sánchez, 2013).

According to Ojeda ( 2016), the Central Bank of Ecuador reported that there was a $22.3 \%$ increase in tree tomato exports during 2010-2014 compared to 2005-2009, which meant 300 thousand dollars in FOB (Free On Board) ${ }^{1}$ value; however, Ecuador's largest competitor in this fruit export is Colombia, which exports five times as much as Ecuador; nevertheless, since January 2017, Ecuador has had ease of entry into the European Union market as its non-oil exports have free access due to the MultiParty Trade Agreement that exempts it from paying $3.6 \%$ custom duties on exports (Delegación de la Unión Europea en Ecuador, 2017). Furthermore, during 2016 Ecuador managed to increase its exports of processed tree tomato into the European market by $80.0 \%$ (USD 782000,0 FOB) compared to 2015 (USD 301000.0 FOB value), where aspects such as

\footnotetext{
1"Fre on board" is an international commercial law used for trading operations in which merchandise transport is done by ship, whether sea or river.
}

estratégicas integradoras que tributen en el bienestar de sus actores.

En la región Sierra Ecuatoriana, durante el periodo 2015-2017, el cultivo de tomate de árbol se incrementó en un $70 \%$, siendo las provincias más sobresalientes Imbabura, Tungurahua y Pichincha. Este crecimiento se genera gracias a las condiciones agroclimáticas que posee esta región, la planificación agrícola establecida por el estado, y el mejoramiento de variedades y productividad del cultivo liderado por el Instituto Nacional de Investigaciones Agropecuarias (MAG, 2017). Las oportunidades de mercado que poseen los productos exóticos en mercados europeos, norteamericanos y asiáticos también son determinantes ya que han motivado el aumento de área para el cultivo de este bien agrícola (INIAP, 2016). Por otro lado, se calcula que existe una producción de 29725.0 toneladas de tomate de árbol por año, donde el $70.2 \%$ es aprovechado por las agroindustrias y empresas exportadoras, mientras que el $29.8 \%$ es comercializado en estado fresco a nivel local y regional. En el mercado mundial, constantemente se genera el requerimiento de productos provenientes de cultivos no tradicionales como el tomate de árbol, maracuyá, naranjilla, piña y uvilla, lo que ha incentivado la diversificación de la producción y exportaciones en el Ecuador (PROECUADOR, 2016).

El tomate de árbol ocupa un sitio importante dentro de los niveles de exportación de frutas. Al ser considerada una fruta exótica, es apetecida por muchas personas, alcanzando altos valores comerciales (Fernández, 2018), además sus características nutricionales la hacen aún más atractiva para su mercado y comercialización (SAE, 2017). No obstante, a nivel nacional esta fruta es poco consumida debido al desconocimiento de los beneficios funcionales y nutricionales que posee, sin embargo, empresas farmacéuticas y biotecnológicas han manifestado las propiedades curativaspreventivas contra enfermedades prostáticas, cardiovasculares, digestivas y cancerígenas (Bojórquez, González, \& Sánchez, 2013).

Según Ojeda (2016), el Banco Central del Ecuador informó que durante el periodo 2010- 2014 ocurrió un incremento del $22.3 \%$ en las exportaciones de 
social responsibility, fair price and respect for the environment are key to consolidating the market for this product (PROECUADOR, 2017).

Tree tomato production is not only intended to export fresh fruit, which seeks to reach the final consumer with its nutritional benefits intact and in its original form (Olsen, 2017), but is also channeled towards its transformation into frozen fruit, purée, pulp, jams, preserves and dehydrated items, with the objective being to diversify its consumption and expand the market. Nonetheless, the highest market value of the Ecuadorian tree tomato is obtained by the fresh fruit and the processed ones that manage to maintain the geometric shape of the fruit, as is the case of canned and glass jar preserves (Guerrero, 2015).

For this reason, the purpose of the study was to analyze in a descriptive manner the structure of the tree tomato agri-food network, considering social and productive factors that will allow the expansion of the abovementioned network and contribute information for the identification of potential problems that require strategic solutions; this was achieved by identifying agents of this crop's production network in the central interAndean region, analyzing the socio-productive factors of each link in the network and identifying the mechanism that dynamizes and controls the production network under study.

\section{Materials and Methods}

The study was carried out in the Inter-Andean region comprising the provinces of Cotopaxi, Tungurahua and Chimborazo (approximately $59810 \mathrm{~km}^{2}$ ). This region is geographically located at $0^{\circ} 42^{\prime} \mathrm{S}$ and $80^{\circ} 00^{\prime} \mathrm{W}$, with an average elevation of $3500 \mathrm{~m}$ and an average temperature fluctuating between 15 and $25^{\circ} \mathrm{C}$ (Graph 1).

A systemic methodology was implemented in this region that sought to detect the main flow of resources throughout the studied production network, as well as to analyze the most relevant socio-productive characteristics of each stage of the network, and identify social, productive and binding trends between the different agents as detailed below. tomate de árbol con respecto al periodo 2005-2009, lo que significó 300 mil dólares en valor FOB (Free On Board)'; sin embargo, el mayor competidor de Ecuador en las exportaciones de este fruto es Colombia en una relación 1 Ecuador, 5 Colombia. No obstante, desde enero del 2017, Ecuador cuenta con la facilidad de ingreso al mercado de la Unión Europea ya que su oferta exportable no petrolera tiene libre acceso gracias al Acuerdo Comercial Multipartes que lo exonera de pagar el $3.6 \%$ de impuestos arancelarios sobre las exportaciones (Delegación de la Unión Europea en Ecuador, 2017). Por otro lado, durante 2016 Ecuador logró incrementar 80.0 \% en sus exportaciones al mercado europeo de tomate de árbol procesado (USD 782 000,0 valor FOB) con respecto al 2015 (USD 301000.0 valor FOB), donde aspectos como responsabilidad social, precio justo y respeto del ambiente, son claves para consolidar el mercado a este producto (PROECUADOR, 2017).

La producción de tomate de árbol no solo está destinada a la exportación de fruta en estado fresco, la misma que busca llegar al consumidor final con sus beneficios nutricionales intactos y forma original (Olsen, 2017), sino también, es canalizada hacia su transformación en fruta congelada, puré, pulpa, mermeladas, conservas y deshidratada, siendo su objetivo la diversificación de consumo y expansión de mercado. No obstante, el mayor valor de mercado de tomate de árbol ecuatoriano está formado por la fruta en estado fresco y los elaborados que logran mantener la forma geométrica de la fruta como es el caso de las conservas en lata o frasco de vidrio (Guerrero, 2015).

Por ello, la finalidad del estudio fue analizar de manera descriptiva la estructura de la red agroalimentaria del tomate de árbol, considerando factores sociales y productivos que permitiese la expansión del conocimiento de la mencionada red y, aporte con información para la identificación de potenciales problemas que requieran de soluciones estratégicas, esto se logró mediante la identificación de agentes de la red productiva de ese cultivo en la zona interandina central, el análisis de factores

"Libre a bordo, puerto de carga convenido" Es un incoterm (una cláusula de comercio internacional) que se utiliza para operaciones de compra-venta en las que el transporte de la mercancía se realiza por barco, ya sea marítimo o fluvial. 


\section{Graph 1. Map of the Ecuadorian territory and the region comprising the provinces of Cotopaxi, Tungurahua and Chimborazo.}

Gráfica 1. Mapa del territorio ecuatoriano y zona comprendida por las provincias Cotopaxi, Tungurahua y Chimborazo.

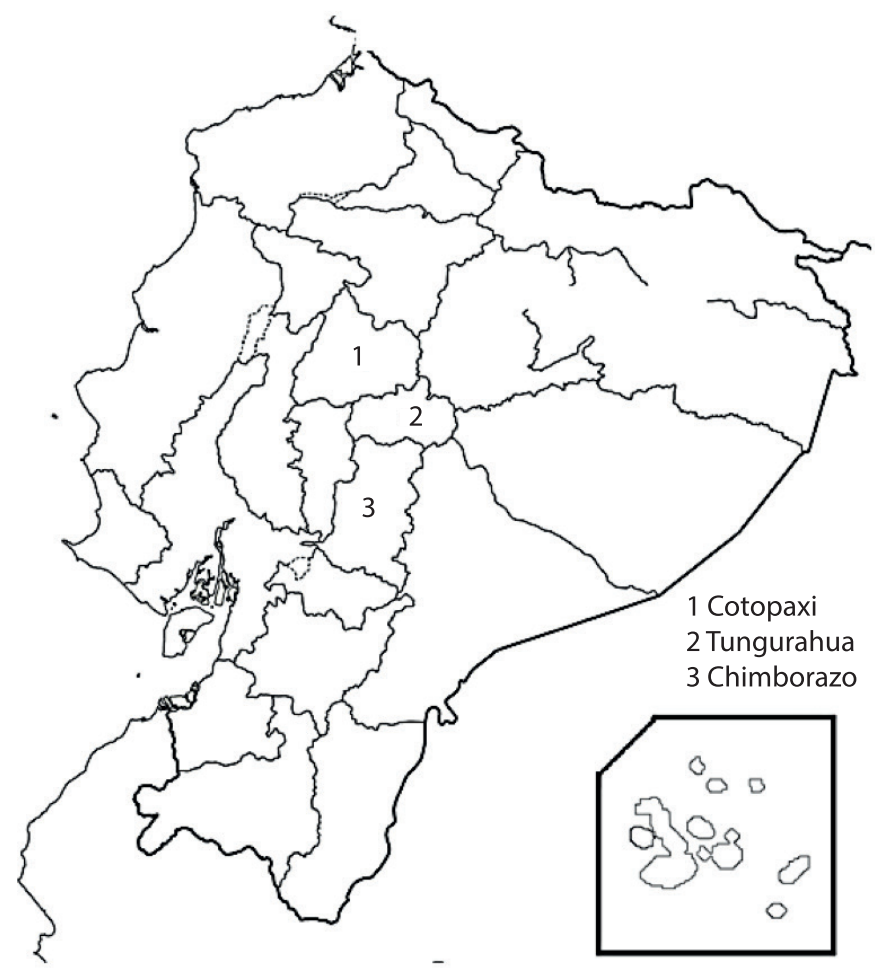

Identification of agents that structure the different stages of the production network

The information from the last census in 2013 generated by the Ministry of Agriculture, Livestock, Aquaculture and Fisheries (MAGAP) was considered, as well as the register of enterprises involved in the tree tomato value chain given by the Ministry of Industry and Productivity (MIPRO). Porter's value chain model was used, grouping agents by stages.

\section{Sample size description}

The continuous variable "Number of tree tomato producers registered by MAGAP" was used to determine the sample size at the producer level in the provinces involved, representing a total of 619 producers (population). The formula reported by Sukhatme (1953) with a $90.0 \%$ confidence level was used, resulting in a minimum sample of 180 producers. The producers' sample was distributed as follows: 48 in the province of Cotopaxi, 75 in socio-productivos de los diferentes eslabones, y la identificación del mecanismo que dinamiza y gobierna la red productiva bajo estudio.

\section{Materiales y métodos}

El estudio se realizó en la zona Interandina comprendida por las provincias de Cotopaxi, Tungurahua y Chimborazo (extensión aproximada de $59810 \mathrm{~km}^{2}$ ). Esta se localiza geográficamente a $0^{\circ}$ $42^{\prime}$ latitud sur y $80^{\circ} 00^{\prime}$ longitud oeste, con una altitud promedio de $3500 \mathrm{~m}$ y una temperatura promedio que oscila entre 15 y $25^{\circ} \mathrm{C}$ (Gráfica 1).

En la zona se aplicó una metodología sistémica que buscó detectar los principales flujos de recursos a lo largo de la red productiva bajo estudio, así como analizar las características socio-productivas más relevantes de cada etapa de la red, identificar tendencias sociales, productivas y vinculatorias entre los diferentes agentes como se detalla a continuación: 
Tungurahua and 57 in Chimborazo, achieving a representativeness of $30.0 \%$ of the total population. For the postproduction stage the information from participating enterprises registered in the Ministry of Industry and Productivity was used.

\section{Analysis of socio-productive aspects}

It was carried out through the implementation of structured surveys and interviews that considered variables of a productive and socioeconomic nature, which gave a diagnosis of the network's current situation.

\section{Production network governance dynamics}

The mechanisms that govern the production network were identified based on the information gathered from the agents through applying the method proposed by Frederick and Gereffi, (2009), which recognizes the links that exercise governance, leadership or control of a chain or a network, highlights the added value generated in different stages, and finally recognizes the most suitable links for economic escalation through strategies.

\section{Results and discussion}

Identification of the agents comprising the stages of the value chain

The evaluation of the objectives and resources of the enterprises engaged in transforming raw material into a finished product allows identifying industrial competitiveness such as: the threat of new market entrants, rivalry among existing competitors, bargaining power of suppliers, bargaining power of buyers and threats of substitute products and services (Herrera \& Baquero, 2018).

The tree tomato production network of the region under study is characterized by the high bargaining power of its producers because the number of participants is relatively small (less than 1000 participants) relative to the number of producers in extensive networks (more than 1000 participants) (Alderete, 2015), such as the blackberry, garlic, vegetable and legume networks. Possibly this is because the demand for tree tomato by industry and the final consumer is still small, so few
Identificación de agentes que conforman las etapas de la red productiva

Se consideró la información del último censo de 2013 generado por el Ministerio de Agricultura, Ganadería y Pesca (MAGAP), y el registro de empresas involucradas en la cadena de valor del tomate de árbol proporcionado por el Ministerio de Industrias y Productividad (MIPRO). Se aplicó el esquema de cadena de valor de Porter, agrupando agentes por etapas.

\section{Descripción del tamaño de la muestra}

Para la determinación del tamaño de la muestra a nivel productor se utilizó la variable continua "Número de productores de tomate de árbol registrados por el MAGAP" de las provincias involucradas, misma que representa un total de 619 productores (población), para ello, se empleó la fórmula reportada por Sukhatme (1953) con un nivel de confianza del $90.0 \%$ obteniéndose como resultado una muestra mínima de 180 productores. La muestra de productores se distribuyó de la siguiente manera: 48 en la provincia de Cotopaxi, 75 en Tungurahua y 57 en Chimborazo, logrando una representatividad del $30.0 \%$ de la población total. Mientras que para la etapa de posproducción se usó la información de empresas participantes registradas en el Ministerio de Industrias y Productividad.

\section{Análisis de aspectos socio-productivos}

Se realizó a través de la aplicación de encuestas $y$ entrevistas estructuradas que contemplaron variables de carácter productivo y socioeconómico, que arrojaron un diagnóstico de la situación actual de la red productiva.

\section{Dinámica de gobernanza de la red productiva}

Se identificaron los mecanismos que gobiernan la red productiva con base en la información recabada de los agentes mediante la aplicación del método propuesto por Frederick y Gereffi, (2009); el mismo que indica reconocer los eslabones que ejercen gobernanza, liderazgo o control de una cadena o red, asimismo resaltar el valor agregado que se genera en las distintas etapas, y finalmente reconocer los eslabones más idóneos para el escalamiento económico mediante estrategias. 
agents are encouraged to cultivate it. However, the Inter-Andean Ecuadorian region, due to its territorial characteristics, capacities and population dynamics, is considered an important commercial node nationally, which is an important competitive advantage for the agents of the network under study.

Figure 1 schematizes the production network with its starting point in support activities, carried out by agents such as public and private production enterprises that provide seeds, machinery, fertilizers and other goods through input flows. Savings and credit cooperatives and the State-owned bank also participate; they are in charge of financing different activities throughout the production network.

According to the information provided by MAGAP presented in Table 1, $1.5 \%$ of all fruit and vegetable producers in the area comprising the provinces of Chimborazo, Cotopaxi and Tungurahua participate in the tree tomato production stage. The province of Tungurahua stands out because

\section{Resultados y discusión}

Identificación de agentes que conforman las etapas de la cadena de valor

La evaluación de los objetivos y recursos de las empresas dedicadas a la transformación de materia prima en producto terminado permite identificar las competencias industriales como: la amenaza de los nuevos competidores, rivalidad entre competidores, poder de negociación de los proveedores, poder de negociación de los clientes y amenazas de servicios y productos sustitutos (Herrera \& Baquero, 2018).

La red productiva del tomate de árbol de la zona bajo estudio se caracteriza por el alto poder de negociación de sus productores, debido a que la cantidad de participantes es relativamente pequeña (menos de 1000 participantes) en relación con el número de productores de redes extensas (más de 1000 participantes) (Alderete, 2015), como son las redes de mora, ajo, hortalizas

Figure 1. Tree tomato production network agents.

Figura 1. Agentes de la red productiva del tomate de árbol.

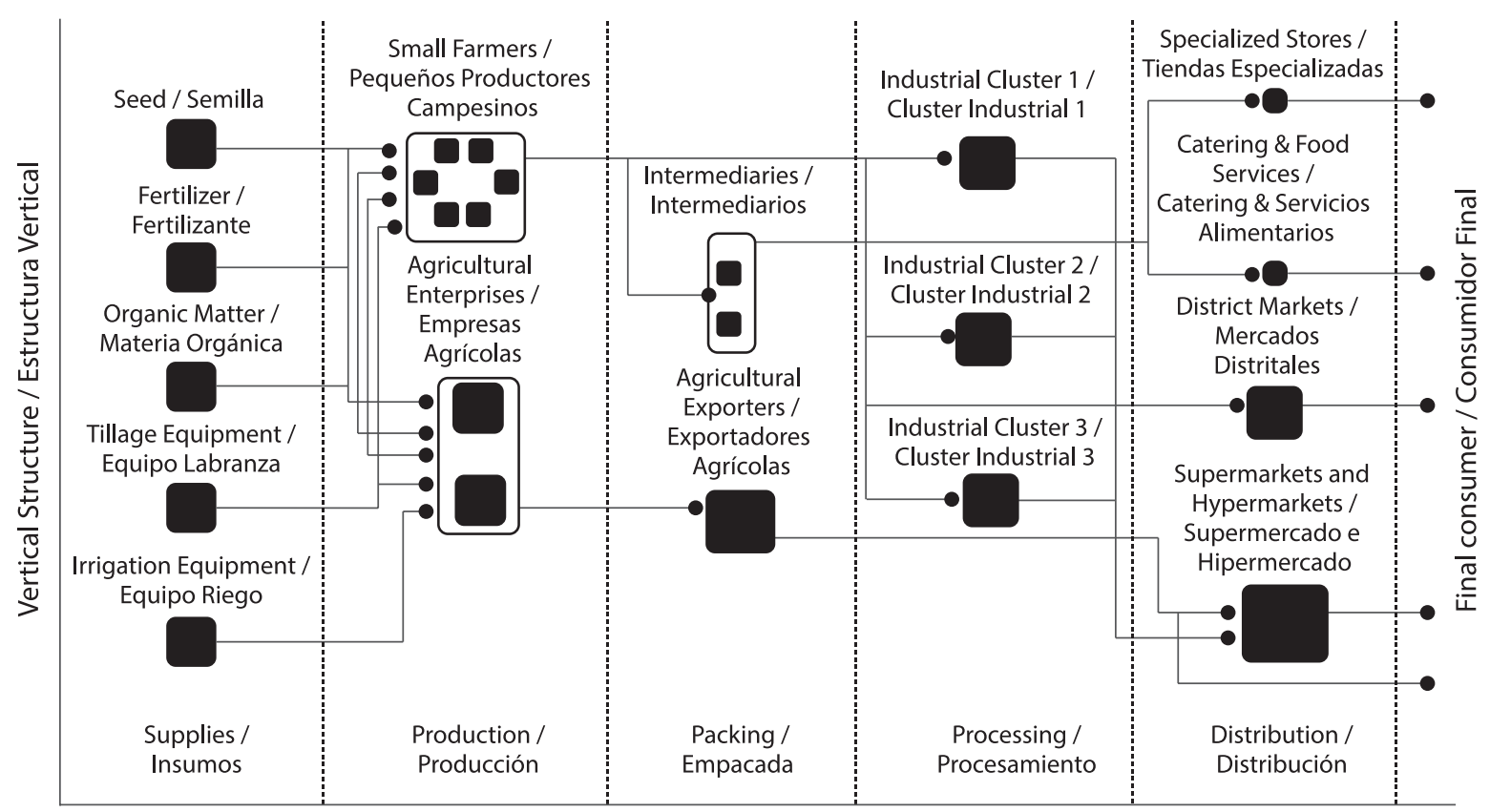

Horizontal Structure / Estructura Horizontal 
Table 1. Number of producers and tree tomato production area in the central region of Ecuador. Cuadro 1. Número de productores y superficie de producción de tomate de árbol en la zona centro de Ecuador.

\begin{tabular}{|c|c|c|}
\hline $\begin{array}{l}\text { Province/ } \\
\text { Provincia }\end{array}$ & $\begin{array}{c}\text { Number of producers registered by } \\
\text { MAGAP / } \\
\text { Número de productores registrados } \\
\text { por el MAGAP }\end{array}$ & $\begin{array}{c}\text { Production area (ha) registered by } \\
\text { MAGAP / } \\
\text { Superficie (ha) de producción registradas } \\
\text { por el MAGAP }\end{array}$ \\
\hline Cotopaxi & 182 & 382,3 \\
\hline Tungurahua & 250 & 485,2 \\
\hline Chimborazo & 210 & 371,1 \\
\hline
\end{tabular}

Source: Ministry of Agriculture, Livestock, Aquaculture and Fisheries-MAGAP, (2015)

Fuente: Ministerio de Agricultura, Ganadería y Pesca - MAGAP, (2015)

it has the largest number of hectares for such production. It is important to note that there is a significant advantage regarding the harvest of this fruit because it is collected every day of the year, so large production volumes can be obtained (CORPOICA, 2009).

The production stage is carried out by individual farmers and agricultural associations and cooperatives; these agents channel their production towards intermediaries, provincial distribution centers, district markets, and private fruit and vegetable processing enterprises. The processors and agents in charge of post-harvest activities channel the production towards brokers, wholesalers, retailers and institutional markets in hotel chains, restaurants and catering services (HORECA); they are in charge of suppling goods generated in the network to the final consumer.

For the post-production stage, 32 enterprises registered with the Ministry of Industry and Productivity were identified. This is the government entity in charge of characterizing the different MSMEs and large enterprises based on the activity and production sector where they intervene. The enterprises are registered according to the main activity they carry out in the production network, as shown in Figure 2.

The gathered information made it possible to identify that $78.3 \%$ of the surveyed enterprises include tree tomato in their business portfolio, either fresh or processed. Only $21.7 \%$ of the enterprises transform tree tomato into products such as juice, y leguminosas. Posiblemente esto se debe a que la demanda de tomate de árbol por parte de la industria y el consumidor final es aún pequeña, por tanto, incentiva a pocos agentes a cultivarlo. Por otro lado, la zona Interandina del Ecuador por sus características territoriales, capacidades y dinámicas poblacionales, es considerada un importante nodo comercial a escala nacional lo que significa una importante ventaja competitiva para los agentes de la red bajo estudio.

La Figura 1, esquematiza la red productiva con su punto de partida en actividades de soporte, llevadas a cabo por agentes como empresas productoras estatales y privadas, que suministran a través de flujos de insumos semillas, maquinaria, fertilizantes, entre otros bienes; de igual forma participan cooperativas de ahorro y crédito, y el banco estatal, quienes son los encargados de financiar las diferentes actividades a lo largo de la red productiva.

De acuerdo con la información proporcionada por el MAGAP presentada en el Cuadro 1, se identificó que para la etapa de producción de tomate de árbol de la zona comprendida por las provincias de Chimborazo, Cotopaxi y Tungurahua se cuenta con el $1.5 \%$ de productores del sector hortofrutícola. A la vez, la provincia de Tungurahua destaca por poseer el mayor número de hectáreas para dicha producción. Es importante mencionar que existe una ventaja significativa en cuanto a la cosecha de esta fruta, ya que se recolecta durante todos los días del año, por lo que se pueden obtener grandes volúmenes de producción (CORPOICA, 2009). 
Figure 2. Distribution of enterprise functions.

Figura 2. Distribución de las funciones de las empresas.

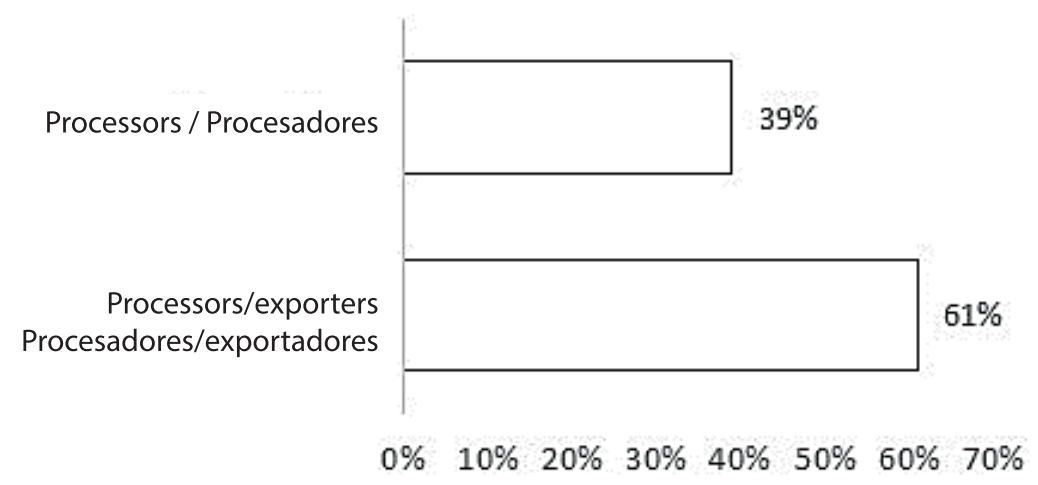

pulp, syrups and dehydrated items. Furthermore, it was identified that $39.1 \%$ of the registered enterprises exclusively operate in the domestic market, $5.0 \%$ only operate in the international market and $55.9 \%$ have participated in both types of markets as shown in Figure 3. On the other hand, of the $60.9 \%$ of enterprises that have had experience in international markets, only $30.4 \%$ have exported products based on tree tomato with added value.

Despite the low percentage of companies that process tree tomato $(21.7 \%)$ into conventional products (juice, preserves and dehydrated items), there are several components of this fruit that can be used to manufacture higher-value foodstuffs, as is the case of bioactive compounds (vitamins, antioxidants) possessed by this fruit. Torres (2012) found in a study conducted on enterprises in the canton of Ambito, province of Tungurahua, that $23.0 \%$ sell tree tomato as fresh fruit, $12.0 \%$ as jam, and $9.0 \%$ for juice making. Additionally, $56.0 \%$ of the companies surveyed showed no interest in transforming it into consumer goods mainly due to a lack of knowledge of its economic, productive and nutritional benefits.

With respect to the distributors registered with the Ministry of Industry and Productivity, three corporations were identified that lead the fresh and processed tree tomato retail market, while the other distributors (10 were identified) are medium-sized wholesalers.
La etapa de producción es ejecutada por agricultores individuales, asociaciones y cooperativas agrícolas, estos agentes direccionan su producción hacia intermediarios, centros de distribución provinciales, mercados distritales y procesadoras privadas de frutas y vegetales. Los procesadores y agentes encargados de actividades de poscosecha direccionan la producción hacia brokers, mayoristas, minoristas y mercados institucionales en cadenas hoteleras, restaurantes y servicios de catering (HORECA), quienes son los encargados de proveer de los bienes generados en la red al consumidor final.

Para la etapa de posproducción, se identificaron 32 empresas registradas en el Ministerio de Industrias y Productividad, quien es el ente gubernamental encargado de caracterizar las diferentes Mipymes y grandes empresas basándose en la actividad y el sector productivo donde intervienen. Las empresas son registradas de acuerdo a la actividad principal que ejecutan dentro de la cadena productiva, como se explica en la Figura 2.

La información recabada permitió identificar que $78.3 \%$ de las empresas encuestadas incluyen tomate de árbol en su cartera de negocios, ya sea en estado fresco o procesado. Solo $21.7 \%$ de las empresas transforma el tomate de árbol en productos como jugos, pulpa, zumo, almíbares y deshidratado. Asimismo, se identificó que $39.1 \%$ de las empresas registradas operan exclusivamente en el mercado doméstico; $5.0 \%$ únicamente en 
Figure 3. Private enterprise participation in the tree tomato market. Figura 3. Participación de empresas privadas en el mercado de tomate de árbol.

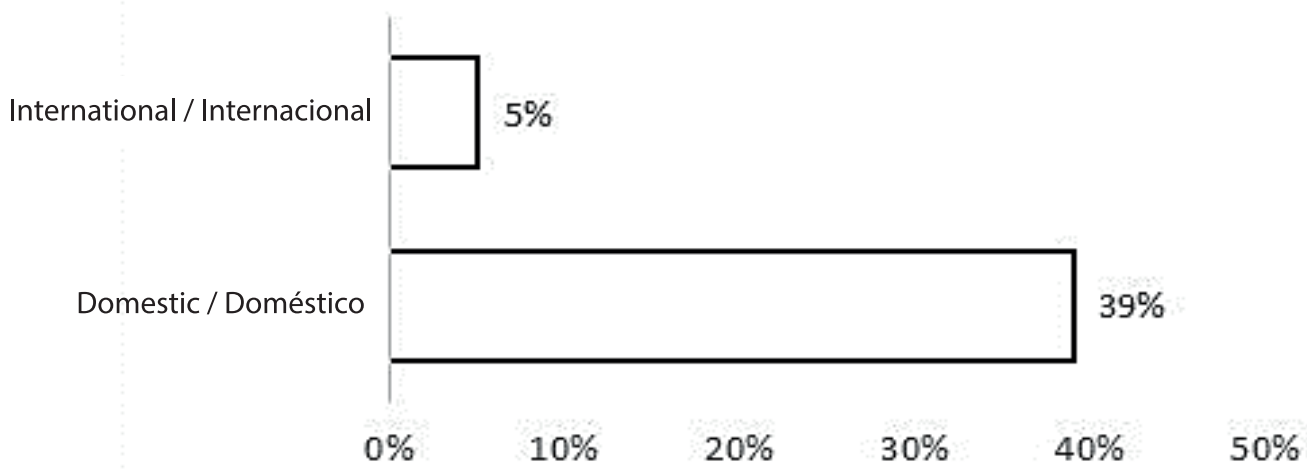

\section{Analysis of socio-productive aspects}

\section{Production}

Socioeconomic factor. This stage has producers between 30 and 50 years old, mostly men (56.0\%), although the inclusion of women has increased by $5.0 \%$ during the past three years as a result of the progressive growth of the tree tomato market. In terms of schooling, $40.0 \%$ have a secondary education and $26.0 \%$ higher education; $28 \%$ of the producers are association members and $39.0 \%$ are cooperative members. Regarding their financing sources, these vary as shown in Figure 4, where their own capital is mostly involved in production and is what possibly prevents the rapid economic growth of this agri-food good.

According to Benavides C. (2012), approximately USD 8000.0 are required to produce 60 ha of tree tomato. Producers in the provinces of Tungurahua and Cotopaxi register loans of USD 17500.0 on average for investment in the production of this agricultural product (Banco Nacional del Fomento, 2012). It is considered an advantage that the production costs for this crop (Table 2 ) are relatively low in Andean countries. By comparison, export income values are five times higher than production costs, resulting in very attractive financial margins for the industry and, therefore, for the country. Guerrero (2015) indicates that the domestic market price for fresh tree tomato is USD $0.85 \mathrm{~kg}^{-1}$, which can vary up el mercado internacional y $55.9 \%$ ha participado en ambos tipos de mercado como se muestra en la Figura 3. Por otro lado, del $60.9 \%$ de empresas que ha tenido experiencia en mercados internacionales, solo $30.4 \%$ ha exportado productos a base de tomate de árbol con valor agregado.

A pesar del bajo porcentaje de transformadores de tomate de árbol (21.7 \%) en productos convencionales (jugos, conservas y deshidratados), existen varios componentes derivados de esta fruta que pueden ser aprovechados para la fabricación de bienes alimenticios de mayor valor, como es el caso de bioactivos (vitaminas, antioxidantes) que esta fruta posee. Torres (2012), afirma mediante un estudio realizado en empresas del cantón Ambato, provincia de Tungurahua, que $23.0 \%$ comercializa tomate de árbol como fruto fresco; $12.0 \%$ como mermelada; $9.0 \%$ lo destina a la elaboración de jugo. 56.0 \% de las empresas encuestadas no mostró interés alguno en transformarlo en bienes de consumo debido principalmente al desconocimiento de sus beneficios económicos, productivos y nutricionales.

Con respecto a los distribuidores registrados por el Ministerio de Industrias y Productividad, se identificaron tres corporaciones que lideran el mercado minorista de tomate de árbol en estado fresco y procesado; mientras que los distribuidores restantes (10 identificados) son empresas medianas de actividad comercial mayorista. 
to USD $1.35 \mathrm{~kg}^{-1}$, whereas the international market fresh price fluctuates between USD 5.50 and $9.50 \mathrm{~kg}^{-1}$; these values include transportation costs, customs duties and cargo insurance (Servicio de Información Agropecuaria, 2008).

Productive Factor. Regarding land tenure, $45 \%$ own land, $29 \%$ of the respondents work collectively and $26 \%$ lease land and use it for agriculture; $55 \%$ of the respondents have an area of land larger than $3 \mathrm{ha}$, and the cultivated area for tree tomato averages between 1.25 to 2.50 ha. At the same time, $56 \%$ uses open-field cultivating techniques.

\section{Análisis de aspectos socio-productivos}

\section{Producción}

Factor socioeconómico. Esta etapa cuenta con productores entre los 30 y 50 años, en su mayoría hombres (56.0\%) aunque la inclusión de mujeres se ha incrementado en un $5.0 \%$ en los últimos tres años gracias al aumento progresivo del mercado de tomate de árbol. La formación académica de sus agentes es: secundaria (40.0\%) y superior (26.0\%). $28 \%$ de los productores son miembros de asociaciones y $39.0 \%$ son socios de cooperativas.

Figure 4. Financing sources for tree tomato producers.

Figura 4. Fuentes de financiamiento de los productores de tomate de árbol.

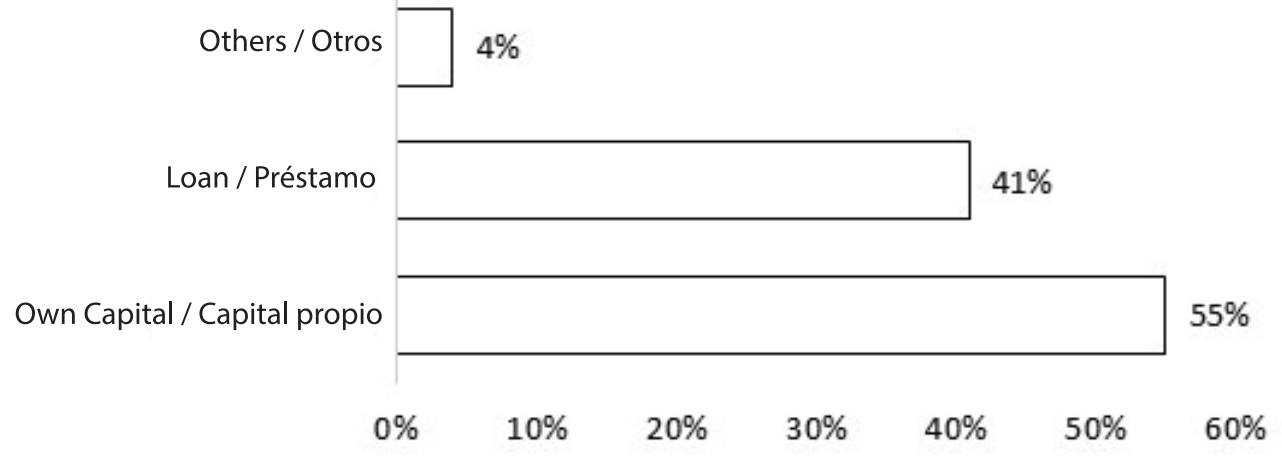

Table 2. Tree tomato production costs.

Tabla 2. Costos de producción de tomate de árbol.

\begin{tabular}{ccc}
\hline & $\begin{array}{c}\text { Establishment / } \\
\text { Establecimiento }\end{array}$ & $\begin{array}{c}\text { Maintenance / } \\
\text { Mantenimiento }\end{array}$ \\
\hline Activity / Actividad & $\%$ & $\%$ \\
\hline Sowing / Siembra & 7 & 1 \\
Fertilization / Fertilización & 14 & 2 \\
Phytosanitary Control /Control fitosanitario & 24 & 5 \\
Cultural Practices / Labores culturales & 42 & 16 \\
Harvest /Cosecha & 11 & 49 \\
\hline
\end{tabular}


The most cultivated genotype is orange giant, followed by the purple New Zealand genotype and to a lesser extent the purple giant (46, 35 and $19 \%$ respectively). According to Chanag-Miramag, Viveros-Rojas, Alvarez-Ordoñez, Criollo-Escobar, \& Lagos-Mora (2017), there are about 29 adapted tree tomato genotypes that differ mainly in color and size. They also mention that in Ecuador there is an orange ecotype adapted to Ecuadorian agroclimatic conditions, which is medium to large in size and sold in the domestic and international market.

Arturo, J. and Goyes, F. (2003) state that Colombia, being the largest producer of tree tomato in the world, mostly cultivates the Colombian orange giant genotype and to a lesser extent the purple giant genotype.

According to the results obtained (average yield $\left.15.2 \mathrm{t} \mathrm{ha}^{-1}\right)$, compared to the yields reported by the Ministry of Agriculture and Rural Development (2014), which mentions that tree tomato yield in Ecuador is $15.3 \mathrm{t} \mathrm{ha}^{-1}$ and in Colombia $15.8 \mathrm{t} \mathrm{ha}^{-1}$, it is observed that the value chain under study has very similar values in this variable. It is also important to note that only $33 \%$ of the producers use post-harvest techniques which consist of: i) harvest distribution in 15-kg plastic containers for transport to storehouses or collection centers; ii) fruit selection according to size (caliber) and ripening stage. The percentage of those who use post-harvest techniques is relatively low due to several factors, such as lack of technical knowledge, low demand and interest in quality from local markets and little involvement by the academic sector in this production network.

\section{Post-production: Processors}

Socioeconomic factor. More than $70 \%$ of the registered enterprises correspond to MSMEs (micro and small enterprises); in addition, medium-sized and large enterprises participating in the tree tomato value chain were identified, as shown in Figure 5. Moreover, $64 \%$ of the registered enterprises are members of associations and $36 \%$ are cooperative members.

Furthermore, in regard to financing, $37 \%$ of the processors mainly operate with their own resources and debt, while $41 \%$ operate through debt and stock exchange shares. This indicates significant
Con respecto a sus fuentes de financiamiento, estas varían como lo muestra la Figura 4, donde el capital propio es el que mayormente interviene en la producción y lo que posiblemente impida un crecimiento económico rápido de este bien agroalimentario.

Según Benavides C. (2012), para la producción de un cultivo de 60 hectáreas de tomate de árbol se requiere aproximadamente de USD 8 000.0. Los agricultores de tomate de árbol de las provincias de Tungurahua y Cotopaxi registran créditos de USD 17 500.0 en promedio para la inversión en la producción del mencionado producto agrícola (Banco Nacional del Fomento, 2012). Se considera como una ventaja que los costos de producción de este cultivo en los países andinos son relativamente bajos, cuya distribución se detalla en el Cuadro 2, mientras que los valores por ingresos de las exportaciones superan cinco veces los costos de producción, generándose así márgenes financieros muy atractivos para la industria y, por tanto, para el país. Guerrero (2015), indica que el precio para el mercado doméstico de tomate de árbol fresco es de USD $0.85 \cdot \mathrm{kg}^{-1} \mathrm{el}$ mismo que puede variar hasta USD $1.35 \cdot \mathrm{kg}^{-1}$; mientras que para el mercado internacional el precio en fresco oscila entre USD 5.50 y $9.50 \cdot \mathrm{kg}^{-1}$ considerando que en estos valores se incluye el costo del transporte, tarifas arancelarias y seguros de carga (Servicio de Información Agropecuaria, 2008).

Factor productivo. En cuanto a la tenencia de la tierra, $45 \%$ posee tierras propias, $29 \%$ de los encuestados labora en sociedad y $26 \%$ arrienda tierras y las dedica a la agricultura. El $55 \%$ de los encuestados posee una extensión de tierra mayor a $3 \mathrm{ha}$, y el área de cultivo para tomate de árbol va entre 1.25 a 2.50 ha en promedio. A la vez, $56 \%$ aplica técnicas de cultivo a campo abierto.

El genotipo mayormente cultivado es el gigante anaranjado, seguido del genotipo morado neocelandés y en menor proporción el morado gigante $(46,35$ y $19 \%$ respectivamente). Según Chanag-Miramag, Viveros-Rojas, Álvarez-Ordoñez, Criollo-Escobar, \& Lagos-Mora (2017) existen cerca de 29 genotipos adaptados de tomate de árbol que se diferencian principalmente por el color y tamaño. Además, mencionan que en Ecuador hay un ecotipo anaranjado adaptado a las condiciones 
capital involvement by third parties, such as savings and credit cooperatives, public and private banking entities, and investors. Additionally, the processor also adopts a certain percentage of the financial risk entailed by productive activity as shown in Figure 6 .

A relevant fact was that $57 \%$ of the enterprises do not buy the fruit when it is of low quality due to mechanical damage, small caliber, insect damage or mold presence, among other reasons, because they perceive it as a risk that could adversely affect the final quality of the processed product, especially dried fruit and syrup. On the other hand, it was established that $43 \%$ of the processors sell tree tomato as second and fourth category products, and their delivery is exclusively to international markets agroclimáticas ecuatorianas, de tamaño mediano a grande y que es comercializado en el mercado nacional e internacional.

Arturo, J. y Goyes, F. (2003), manifiestan que Colombia siendo el mayor productor de tomate de árbol en el mundo, cultiva mayormente el genotipo colombiano anaranjado gigante $y$ en menor proporción el genotipo morado gigante.

De acuerdo con los resultados obtenidos (rendimiento promedio $15.2 \mathrm{t} \cdot \mathrm{ha} \mathrm{a}^{-1}$ ), comparados con los rendimientos reportados por el Ministerio de Agricultura y Desarrollo Rural (2014), quienes mencionan que el rendimiento de tomate de árbol para Ecuador es de $15.3 \mathrm{t} \cdot \mathrm{ha}^{-1}$ y para Colombia de $15.8 \mathrm{t} \cdot \mathrm{ha}^{-1}$, se observa que la cadena de valor bajo

Figure 5. Types of enterprises participating in the tree tomato value chain.

Figura 5. Tipos de empresas participantes en la cadena de valor de tomate de árbol.

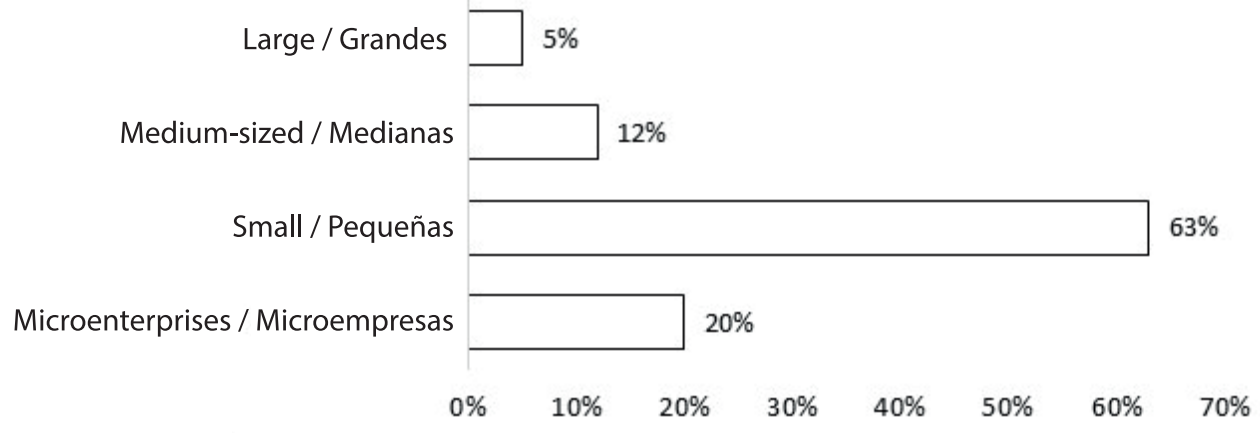

Figure 6. Financing sources for tree tomato processors.

Figura 6. Fuentes de financiamiento de los procesadores de tomate de árbol.

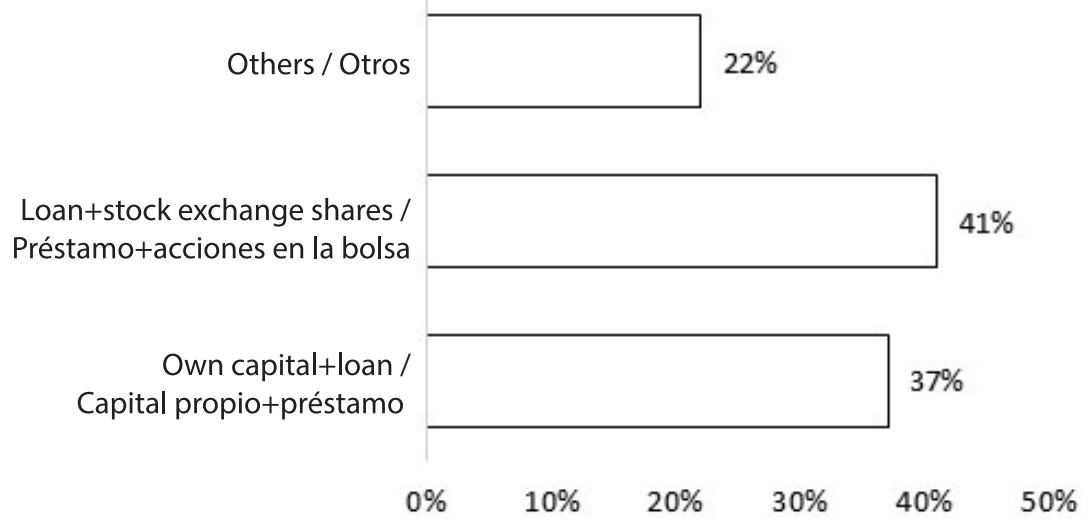


(36\%) and exclusively to domestic markets (49\%); the remaining percentage of processors do it both ways. Additionally, it was found that processors are governed by thorough sanitary controls implemented by the National Agency for Sanitary Regulation, Control and Surveillance (ARCSA) during the whole fruit transformation process, which generates additional costs that increase the final selling price to the consumer (Montilla et al., 2016).

However, it is possible to market tree tomato not only as fresh fruit, but also in an endless number of products that can be sold in the domestic and international market, as indicated by Galarza (2010), who mentions that products such as yoghurt, nectar, syrup and filled chocolates are most often made with tree tomato as the main ingredient.

\section{Postproduction: Distributors}

Socio-economic factor. Among distributors, $50 \%$ are MSMEs and the other $50 \%$ are large enterprises; $50 \%$ of the distributors are members of associations and $100 \%$ do not belong to cooperatives. On the other hand, regarding financing, $72 \%$ operate mostly with their own resources and debt, and $28 \%$ operate through debt and stock market shares.

Tree tomato products are marketed by wholesale and retail distributors; retailers channel the product towards the final consumer (Equipo OCE Nueva York, 2018), whereas wholesalers are responsible for the logistics involved in the export of such products, and are the ones who agree on the prices, supply periods and payment terms, among other aspects (Hinojosa \& Ipiales, 2012). It should be mentioned that pulp is the main Ecuadorian tree tomato product marketed internationally because it retains its nutritional and vitamin properties after being minimally processed and frozen at $-20^{\circ} \mathrm{C}$. Importantly, Equipo OCE Nueva York (2018) reports that worldwide consumption of fruit pulp is expected to grow by about 4 million tons by 2020 , of which $10 \%$ is contributed by tree tomato and other types of berries. In terms of pulp exports to the United States, Ecuador ranks 19 with a $1 \%$ share.

It is important to mention that Ecuador has created export alliances with the European Union, Germany being the target market for the distribution of these products (Osorio, 2013). A clear example of exports is the Tungurahua Fruit Growers association estudio presenta valores muy similares en esta variable. Adicionalmente, es importante mencionar que solo $33 \%$ de los productores aplican técnicas de poscosecha que consisten en: i) distribución de la cosecha en contenedores plásticos de $15 \mathrm{~kg}$ de capacidad para su transporte a bodegas o centros de acopio; ii) selección de la fruta por tamaño (calibre) y estado de madurez. El porcentaje de quienes aplican técnicas de poscosecha es relativamente bajo debido a varios factores, como falta de conocimiento técnico, poca exigencia e interés de calidad en mercados locales y escasa intervención por parte del sector académico en esta red productiva.

\section{Posproducción: Procesadores}

Factor socioeconómico. De las empresas registradas se identificó que más del $70 \%$ corresponde a Mipymes (micro y pequeñas empresas); asimismo se identificaron medianas y grandes empresas participando en la cadena de valor de tomate de árbol como lo muestra la Figura 5. El $64 \%$ de las empresas registradas son miembros de asociaciones y $36 \%$ son socios de cooperativas.

Por otro lado, con respecto al financiamiento, $37 \%$ de los procesadores opera mayormente con recursos propios y deuda, mientras que $41 \%$ lo ejecuta mediante deudas y acciones en la bolsa. Esto indica una importante intervención del capital de terceros como cooperativas de ahorro y crédito, entidades bancarias públicas y privadas e inversionistas. Asimismo, se observa que el procesador también adopta cierto porcentaje del riesgo financiero que implica la actividad productiva como lo muestra la Figura 6.

Un dato relevante fue que $57 \%$ de las empresas no lleva a cabo la compra de fruta cuando es de baja calidad, ya sea por daños mecánicos, calibre pequeño, daños por insectos y presencia de moho entre otras razones, debido a que lo perciben como un riesgo que va en desmedro de la calidad final del producto procesado, principalmente de fruta deshidratada y en almíbar. Por otro lado, se estableció que $43 \%$ de los procesadores comercializan tomate de árbol en segunda y cuarta gamma, y su entrega la realizan en mercados exclusivamente internacionales (36\%), y en mercados exclusivamente nacionales (49\%); el $15 \%$ 
which does not require an intermediary for distribution in view of its product being introduced to the German market with an export of 500 kilograms of organic tree tomato. It was also shown that during 2011-2015 there was an annual average growth rate of 3.7 and $12.3 \%$ in FOB value and volume respectively (EIComercio, 2018).

\section{Market Aspects}

Demand

International prices. In 2016 the average price of tree tomato rose by $4 \%$ over the previous year. The average value of this product in U.S. markets during the studied year was USD 41.6.package of 30-42 units $^{-1}$.

Domestic prices. In contrast to the trend observed in international prices, the tree tomato domestic price in 2016 decreased by $5 \%$ in relation to 2015. The average producer-level price for 2016 was USD $0.85 \mathrm{~kg}^{-1}$ (Figure 7).

\section{Supply}

Domestic export. Exports in Ecuador during 2016 increased by $70 \%$. This behavior reflects the sustained increase in international trade of the tree tomato since in the previous year there was a $13 \%$ increase. Ecuadorian tree tomato exports during 2016 restante de procesadores lo hace en ambos formatos. Adicionalmente, se observó que los procesadores se rigen por controles sanitarios minuciosos, ejecutados por la Agencia Nacional de Regulación, Control y Vigilancia Sanitaria (ARCSA) durante todo el proceso de transformación de la fruta, lo que genera costos adicionales que incrementan el precio final de venta al consumidor (Montilla et al., 2016).

Por otro lado, es posible que la comercialización de tomate de árbol no solo se realice como fruta fresca, sino que existe un sinnúmero de productos que pueden ser comercializados en el mercado nacional e internacional, tal y como lo indica Galarza (2010), quien menciona que productos como yogurt, néctar, almíbar y chocolates rellenos, son los mayormente fabricados y utilizan como ingrediente principal dicho fruto.

\section{Posproducción: Distribuidores}

Factor socioeconómico. Entre los distribuidores se identificó que $50 \%$ son Mipymes y el $50 \%$ restante son grandes empresas. El $50 \%$ de los distribuidores son miembros de asociaciones y el $100 \%$ no pertenecen a cooperativas. Por otro lado, con respecto al financiamiento, $72 \%$ de ellas operan mayormente con recursos propios y deuda y $28 \%$ lo ejecuta mediante deudas y acciones en la bolsa de valores.

Figure 7. Domestic prices for tree tomato producer and wholesalers during 2013-2016.

Figura 7. Precios nacionales para productor y mayoristas de tomate de árbol durante los años 2013-2016.

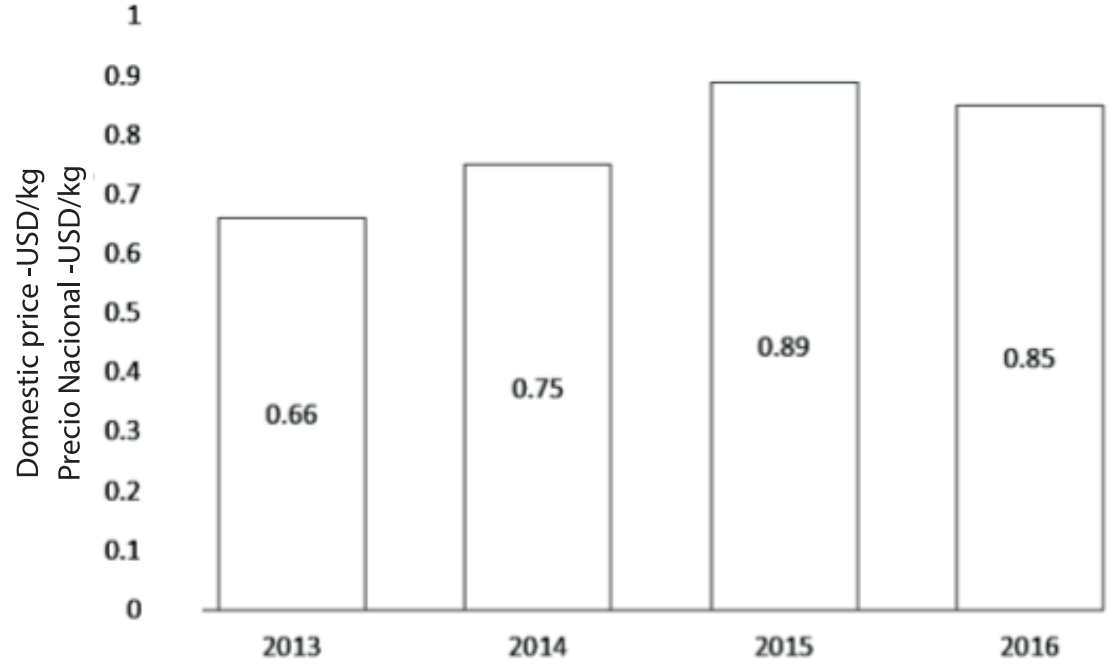


recorded their highest traded volume during March (31t).

\section{Tree tomato value chain governance dynamics}

Governance analysis allows one to understand how a chain is controlled and coordinated when certain actors in the chain have more power than others. Gereffi (2009) defined governance as "relationships of authority and power that determine how financial, material, and human resources are allocated and flowed within a chain."

Figure 8 outlines the governance dynamics of the Ecuadorian tree tomato production network. In this diagram, the complexity of the information shared among the actors in the chain, the coding of that information and the level of competitiveness of the supplier are clarified. According to the classification proposed by Frederick and Gereffi, (2009), the governance dynamics identified is that of the market because transactions are repetitive and easy to code. Agreements and businesses are characterized by spot prices or contracts that provide short payment
La comercialización de productos de tomate de árbol es ejecutada por distribuidores mayoristas y minoristas; por un lado, los minoristas (retailers) canalizan los productos hacia el consumidor final (Equipo OCE Nueva York, 2018), mientras que los mayoristas son los encargados de la logística que implica la exportación de dichos productos, y son quienes acuerdan precios, periodos de suministro y condiciones de pago, entre otros aspectos (Hinojosa \& Ipiales, 2012). Cabe mencionar que el principal producto de tomate de árbol ecuatoriano comercializado a nivel internacional es la pulpa, esto debido a que el ítem conserva sus propiedades nutricionales y vitamínicas al ser mínimamente procesado y congelado a $-20{ }^{\circ} \mathrm{C}$. Es importante recalcar que el Equipo OCE Nueva York (2018) menciona que para el año 2020 se espera que el consumo mundial de frutas en pulpa crezca alrededor de 4 millones de toneladas, de los cuales $10 \%$ sea tributado por tomate de árbol y otro tipo de bayas. En cuanto a las exportaciones para Estados

Figure 8. Governance dynamics of the tree tomato production network in Ecuador.

Figura 8. Dinámica de gobernanza de la red productiva de tomate de árbol en Ecuador.

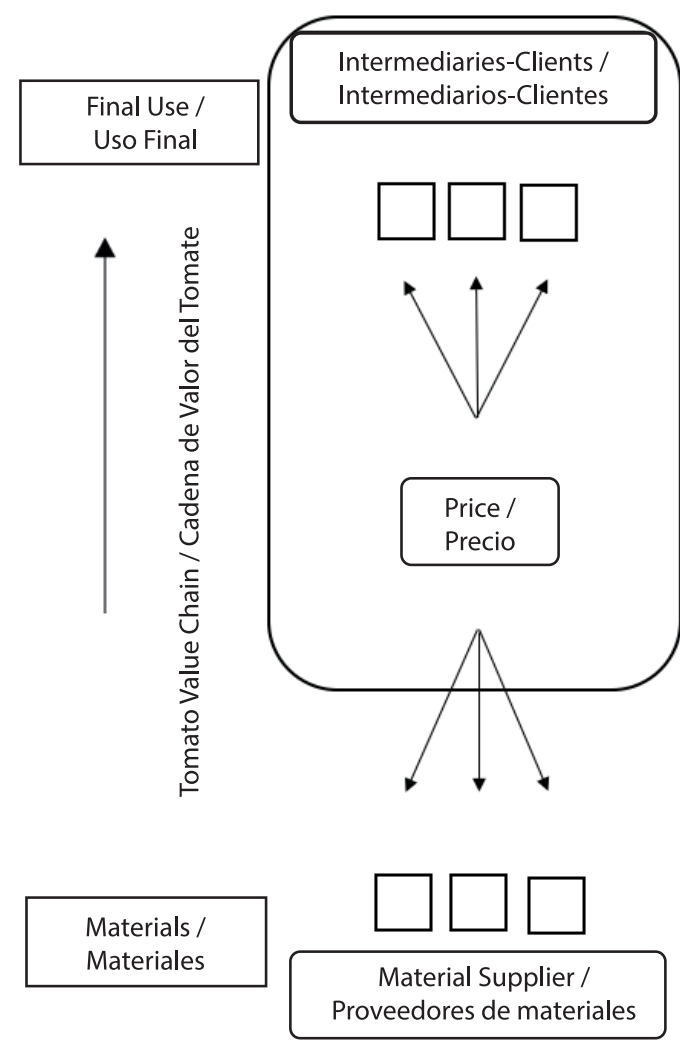


periods and are under the market framework established by the country's central government.

Another important aspect is the transactional cost, which is characterized by being relatively low. In addition, both the buyer and the seller do not require prior coordination or cooperation in defining the product because the aforementioned locations have specialized in growing tree tomato for a few decades, as the industry has developed strategies to diversify the portfolio of products that manage to channel fresh raw material production towards value-added goods.

\section{Conclusions}

Public and private institutions are involved in the Ecuadorian tree tomato production network, participating mainly in the resource allocation stage (seeds, fertilizers, agrochemicals and capital, among others) as a support activity; this stage constitutes the beginning of the tangible resource flow necessary for the performance of the production network.

The production stage has favorable sociodemographic characteristics, such as the involvement of relatively young participants whose ages range from 30 to 40 years, and the inclusion of women in the production network over the past three years thanks to the market opportunities. In the same manner, the production network presents aspects that require attention, for example, technological training for producers in areas such as post-harvest handling, transport logistics and food quality, as well as the strengthening of associative structures based on tangible benefits that encourage greater participation of the producers in the network. A relevant aspect that also needs attention is the productive one because it requires a significant increase in the area allocated to the crop and the application of production systems under greenhouse conditions that allow for an increase in yield.

The tree tomato production network in the inter-Andean region has a post-production stage that clearly defines the actions of processors and distributors. Small enterprises are the ones most involved in value-added activities and a very significant percentage of them belong to associations. On the other hand, distribution
Unidos de fruta en pulpa, Ecuador se encuentra en el puesto 19 con una participación del $1 \%$.

Es relevante indicar que Ecuador ha creado alianzas de exportación con La Unión Europea, siendo Alemania el mercado objetivo para la distribución de estos productos (Osorio, 2013). Un claro ejemplo de las exportaciones es la asociación de Fruticultores de Tungurahua quien no requiere de un intermediario para su distribución en vista de que su producto fue introducido al mercado alemán con una exportación de 500 kilogramos de tomate de árbol orgánico. Así también se evidenció que en el periodo 2011-2015 hubo una tasa de crecimiento promedio anual del 3.7 y $12.3 \%$ en valor FOB y en volumen respectivamente (EIComercio, 2018).

\section{Aspectos de Mercado}

\section{Demanda}

Precios a nivel internacional. En el año 2016 el precio promedio de tomate de árbol aumentó el $4 \%$ en relación con el año anterior. Los valores promedio de este producto en los mercados de Estados Unidos durante el año estudiado, registran los 41.6 USD.paquete de 30-42 unidades ${ }^{-1}$.

Precios a nivel nacional. En contraste a la tendencia observada en los precios internacionales, el precio nacional de tomate de árbol a nivel productor en 2016 presentó una disminución de $5 \%$ con relación al 2015. El precio promedio a nivel de productor para el año 2016 fue de 0.85 USD $\cdot \mathrm{kg}^{-1}$ (Figura 7).

\section{Oferta}

Exportaciones a nivel nacional. Las exportaciones en el Ecuador durante el año 2016 registraron un incremento de $70 \%$. Dicho comportamiento refleja el incremento sostenido del comercio internacional del rubro mencionado puesto que en el año anterior existió un incremento de $13 \%$. Las exportaciones ecuatorianas de tomate de árbol durante el año 2016 registraron su mayor volumen comercializado en el mes de marzo (31 t).

\section{Dinámica de gobernanza de la cadena de valor del tomate de árbol}

El análisis de gobernabilidad permite comprender cómo se controla y coordina una cadena cuando 
enterprises also have an important sense of associativity, but are characterized by the business model with which they operate; for example, they participate in the stock exchange and implement trading methods under credit that generate positive cash flows.

End of English version

\section{References / Referencias}

Alderete, M. (2015). Redes de Pymes. Una visión desde las teorías de club y de equipo. Revista de Economía Institucional. Disponible en http://www.scielo.org.co/ pdf/rei/v17n32/v17n32a12.pdf.

Arras, A., Fierro, L., Jáquez J., \& López J. (2017). Collaboration networks, Enterprise strategy in the insertion to value chain. Revista Mexicana de Agronegocios (en línea). Disponible en http://www.redalyc.org/ pdf/141/14111976007.pdf.

Arturo, J., \& Goyes, F. (2003). Caracterización biológica de un virus en tomate de árbol (Solanum betaceum) presente en el Departamento de Nariño. Trabajo de grado. Facultad de Ciencias Agrícolas. Universidad de Nariño, San Juan de Pasto, Colombia.

Banco Nacional del Fomento. Gerencia de crédito y estadística. (2012). Disponible en https://contenido. bce.fin.ec/documentos/PublicacionesNotas/Catalogo/ Anuario/80anios/Notas185anios.pdf.

Benavides, C. A. (2012). Evaluación de 40 genotipos de tomate de árbol (Cyphomandra betacea (Cav.) Sendt) en la zona de Nariño. Tesis de Maestría. Facultad de Ciencias Agrícolas, Universidad de Nariño, San Juan de Pasto, Colombia.

Blandon, J., Henson, S., \& Cranfield, J. (2008). Small-Scale Farmer Participation in New Afri-Food Supply Chains: Case of the Supermarket Supply Chain for Fruit and Vegetables in Honduras. The International Journal of Developmental. 96, 971-984. https://doi.org/10.1002/ jid.1490. Disponible en https://onlinelibrary.wiley.com/ doi/abs/10.1002/jid.1490.

Bojórquez, R., González, J., \& Sánchez, P. (2013). Propiedades funcionales del licopeno. Nutr. Hosp. vol.28 no.1 Madrid http://dx.doi.org/10.3305/ nh.2013.28.1.6302. ciertos actores de la cadena tienen más poder que otros. Gereffi (2009) definió la gobernabilidad como "relaciones de autoridad y poder que determinan cómo los recursos financieros, materiales y humanos se asignan y fluyen dentro de una cadena.

La Figura 8 esquematiza la dinámica de gobernanza de la red productiva de tomate de árbol en Ecuador. En este esquema la complejidad de la información compartida entre los actores de la cadena, la codificación de dicha información y el nivel de competencia del proveedor son esclarecidos. Según la clasificación propuesta por Frederick y Gereffi, (2009); la dinámica de gobierno identificada es la de mercado debido a que las transacciones son repetitivas y fáciles de codificar. Los acuerdos y negocios se caracterizan por precios al contado o contratos que contemplan periodos de pago cortos y que se sustentan bajo leyes de mercado establecidas por el Gobierno Central del país.

Otro de los aspectos importantes es el relacionado a los costos transaccionales, que se caracterizan por ser relativamente bajos. Asimismo, tanto el comprador como el vendedor no requieren de coordinación previa o cooperación en la definición del producto, debido a que las localidades mencionadas se han especializado en el cultivo de tomate de árbol durante algunas décadas, ya que la industria ha desarrollado estrategias para diversificar la cartera de productos que logran canalizar la producción de materia prima en estado fresco hacia bienes con valor agregado.

\section{Conclusiones}

En la red productiva del tomate de árbol ecuatoriano, se involucran instituciones públicas y privadas, quienes participan principalmente en la etapa de dotación de recursos (semillas, fertilizantes, agroquímicos y capital, entre otros) como actividad de soporte; esta etapa se constituye en el inicio del flujo de recursos tangibles necesarios para el desempeño de esta red productiva.

La etapa de producción cuenta con características sociodemográficas favorables, como la intervención de participantes relativamente jóvenes, cuya edad oscila entre los 30 y 40 años, así como la inclusión de mujeres a la red productiva en los últimos tres 
CEPAL, FAO, \& IICA. (2015). Perspectivas de la Agricultura y del Desarrollo Rural en las Américas. Instituto Interamericano de Cooperación para la Agricultura. Disponible en: http://www.iica.int/sites/default/files/ publications/files/2015/b3695e.pdf.

Chañag-Miramag, H., Viveros-Rojas, J., ÁlvarezOrdoñez, S., Criollo-Escobar, H., \& Lagos-Mora, L. (2017). Evaluación de genotipos de tomate de árbol [Cyphomandra betacea (Cav.) Sendt.] frente al ataque de Phytophthora infestans (Mont.) de Bary sensu lato. Revista Colombiana de Ciencias Hortícolas, vol.11 no.1 Bogotá Diponible en https://dx.doi.org/10.17584/ rcch.2017v11i1.4725

CORPOICA. (2009). Corporación Colombiana de Investigación Agropecuaria. Manual de Manejo Cosecha y Poscosecha de Tomate de Árbol. Bogota. 98p.

Delegación de la Unión Europea en Ecuador. (2017). Cómo Conocer Mejor el Mercado Europeo, Comercio de Bienes entre la Unión Europea y Ecuador. Disponible en https://eeas.europa.eu/sites/eeas/files/20150505_ triptico_acuerdo_ue_ecuador_es.pdf.

El Comercio. (2018). EE UU abre su mercado al tomate de árbol de Ecuador. Reporte Técnico. Disponible en https://www.elcomercio.com/.../estadosunidosmercado-tomate-arbol-ecuador.html.

Equipo OCE Nueva York. (2018). Tomate de Árbol, Mango, piña, uvilla y banana deshidratada en el mercado de los Estados Unidos. Disponible en https://www. proecuador.gob.ec/mango-pina-uvilla-y-bananadeshidratada-en-el-mercado-de-los-estados-unidosmarzo-2018/.

FAO. (2010). Aspectos Generales del Sector Hortofrutícola.

Food and Agriculture Organization of the United Nations, Disponible en http://www.fao.org/ag/ agn/pfl_report_en/_annexes/Annex4/Ecuador/ Importancesummary.xls.

FAO. (2010). Food and Agriculture Organization of the United Nations. Disponible en http://www.fao.org/ ag/agn/pfl_report_en/_annexes/Annex4/Ecuador/ Importancesummary.xls.

FAO. (2011). Pérdidas y Desperdicios de Alimentos en el Mundo. Food and Agriculture Organization of the United Nations. Disponible en http://www.fao.org/3/ai2697s.pdf.

Fernandez, D. (2018). Plan de Negocios para la Comercialización de Tomates de Árbol Orgánicos en Almíbar hacia Alemania. Obtenido de http://dspace. años gracias a las oportunidades de mercado. De igual manera, la red productiva presenta aspectos que requieren atención, por ejemplo, la formación del conocimiento técnico de sus productores en temáticas como poscosecha, logística de transporte y calidad alimentaria, así como el fortalecimiento de estructuras asociativas en función de beneficios tangibles, que incentiven una mayor participación de los productores en la red. Un aspecto relevante que también necesita atención es el productivo, debido a que se requiere del aumento significativo del área asignada al cultivo y la aplicación de sistemas de producción bajo invernadero que permitan incrementar los rendimientos.

La red productiva del tomate de árbol en la zona interandina presenta una etapa de posproducción que define claramente el accionar de procesadores y distribuidores. Pequeñas empresas son las que mayormente participan en las actividades de valor agregado y presentan un porcentaje muy importante de pertenencia a asociaciones. Por otro lado, las empresas distribuidoras también presentan un importante sentido de asociatividad, pero se caracterizan por el modelo de negocios con el que operan, por ejemplo, participar en la bolsa de valores, implementar métodos de negociación bajo crédito que generen flujos de efectivo positivos.

Fin de la versión en español

udla.edu.ec/bitstream/33000/8585/1/UDLA-EC-

TINI-2018-03.pdf.

Frederick, \& Gereffi. (2009). Value Chain Governance: Briefing Paper, Duke University. Disponible en https:// www.researchgate.net/publication/259999285_Value_ Chain_Governance_Briefing_Paper

Galarza, M. (2010). Evaluación de Canales de Comercialización del Tomate de Árbol. Trabajo de Posgrado. Facultad de Ciencias Agropecuarias. Universidad de Cuenca. Un. Press.

Gereffi, G. (2009). Las cadenas productivas como marco analítico para la globalización. Problemas Del Desarrollo. Revista Latinoamericana De Economía, vol.32, no.125. Disponible en https://doi.org/10.22201/ iiec.20078951e.2001.125.7389 
Gereffi, G., \& Fernandez-Stark, K. (2016). Global Value Chain Analysis: A Primer $2^{\text {nd }}$ Edition, Technical Report, Duke CGGC (Center on Globalization, Governance \& Competitiveness), Duke University, Research Gate. Disponible en https://www.researchgate. net/publication/305719326_Global_Value_Chain_ Analysis_A_Primer_2nd_Edition.

Glas Espinel, J., Alvarado Espinel, V., León Abad, S., \& Parra Fonseca, J. C. (2015). Política Industrial del Ecuador 2016-2025, Ministerio de Industrias y Productividad. Disponible en http://www.industrias.gob.ec/wpcontent/uploads/2017/01/politicalndustrialweb-16-dic16-baja.pdf.

Guerrero, G. (2015). Análisis de las Ventajas Competititvas y Comparativas de la Exportación del Tomate de Árbol frente a Colombia y Perú. Trabajo de Grado. Facultad de Ciencias Económicas y Negocios. Universidad Tecnológica Equinoccial. Un. Press.

Herrera, R., \& Baquero, M. (2018). Las 5 fuerzas de Porter. Universidad de Chile. Disponible en http://www. elmayorportaldegerencia.com/Documentos/ Emprendedores/[PD]\%20Documentos\%20-\%205\%20 fuerzas\%20de\%20porter.pdf.

Hinojosa , M. J., \& Ipiales, M. V. (2012). Estrategia de fortalecimiento de la cadena productiva de la uvilla como aporte al desarrollo de las zonas rurales de la provincia de Imbabura, Facultad de Ciencias Económicas, Universidad Central del Ecuador. Disponible en http://www.dspace.uce.edu.ec/ bitstream/25000/1639/1/T-UCE-0005-286.pdf.

Hirschman, A. (1958). The strategy of economic development. American Journal of Agricultural Economics, Volume 41, Issue 2, 1 May 1958, Pages 468-469, https://doi.org/10.2307/1235188. Disponible en https://academic.oup.com/ajae/articleabstract/41/2/468/156133.

IFAD. (2011). The International Fund for Agricultural Development. Obtenido de https://www.ifad. org/documents/10180/f2136c2e-3b40-4074-9b71bfac80efc410.

INIAP. (2016). Instituto Ecuatoriano de Investigaciones Agropecuarias. Boletín Situacional. Tomate de árbol. Disponible en: http://fliphtml5.com/ijia/efww/basic.

MAG. (2017). Ministerio de Agricultura y Ganadería. Coordinación General del Sistema de Información Nacional. Zonificación Agroecológica Económica del Cultivo de Tomate de Árbol en el Ecuador Continental.
Disponible en http://www.agrocalidad.gob.ec/ documentos/dia/guia-tomate-arbol-min.pdf.

MAGAP. (2015). La Política Agropecuaria Ecuatoriana. Hacia el Desarrollo Territorial Rural Sostenible 2015-2025, Ministerio de Agricultura, Ganaderia, Acuacultura y Pesca. Obtenido de http://servicios.agricultura. gob.ec/politicas/La\%20Pol\%C3\%ADticas\%20 Agropecuarias\%20al\%20\%202025\%201\%20parte.pdf. MAGAP. (2015). Ministerio de Agricultura, Ganadería, Acuacultura y Pesca la Política Agropecuaria Ecuatoriana. Hacia el Desarrollo Territorial Rural Sostenible 2015-2025. Ministerio de Agricultura, Ganadería, Acuacultura y Pesca. Obtenido de http://servicios.agricultura.gob.ec/politicas/La\%20 Pol\%C3\%ADticas\%20Agropecuarias\%20al\%20\%20 2025\%20I\%20parte.pdf.

Ministerio de Agricultura y Desarrollo Rural. (2014). Evaluación Agropecuaria - Tomate de Árbol, 201a Disponible en http://www.agronet.gov.co/ Documents/Tomate\%20de\%20\%C3\%81rbol.pdf.

Miranda, L. (2011). Current State of Colombian Fruticulture and Perspectives for Its Development. Bras. Frutic 2011, 199-205.

Montilla, F., Ceballos, R., Guerrero, A., Narváez, P., Romero, E., \& Villareal, M. (2016). Desarrollo rural con enfoque territorial DRET. Organización Internacional para las Migraciones. Disponible en http://www.oim.org.co/ sites/default/files/Anexo\%20H_\%20Ficha\%20de\%20 proyecto\%20de\%20Uvilla.pdf.

Ojeda, I. (2016). Análisis de oportunidades de negocio para el tomate de árbol. Trabajo de tesis de pregrado. Disponible en https://dspace.ups.edu.ec/ bitstream/123456789/4306/1/UPS-QT03609.pdf.

Olsen, A. (2017). Exportación de Mermelada de Tomate de Árbol Hacia los Estados Unidos. Trabajo de Posgrado, Facultad de Ciencias Administrativas y Recursos Humanos. Universidad San Martín de Porres. Disponible en http://www.repositorioacademico. usmp.edu.pe/bitstream/usmp/3038/1/saravia_ao.pdf.

Orjuela Castro, J. A., Castañeda Calderón, C. A., \& Calderón, M. E. (2008). Análisis de la cadena de valor en las estructuras productivas de uvilla y tomate de árbol en la Provincia de Sumapaz y el Distrito Capital.Tesis de grado. Disponible en https://dialnet.unirioja.es/ servlet/articulo?codigo $=4797195$.

Osorio, G., (2013). Proyecto de Factibilidad para la Exportación de Tomate de Árbol para el Mercado Mexicano. Trabajo 
de Grado. Escuela de Comercio Exterior. Facultad de Ciencias Económicas y Negocios - UTE.

Paez, C. (2018). El Régimen Impositivo a la Propiedad Agrícola en el Ecuador y los Perjuicios Socioeconómicos que Causó su Existencia. Universidad Central del Ecuador - Quito. Obtenido de http://www. dspace.uce.edu.ec/bitstream/25000/16600/1/T-UCE0013-JUR-068.pdf.

PROECUADOR. (2016). Boletín de Inteligencia de Mercados Agosto- Septiembre. Instituto de Promoción de Exportaciones e Inversiones. Disponible en https:// issuu.com/pro-ecuador/docs/boletindic_eneh.

PROECUADOR. (2017). Boletín de Comercio Exterior. Instituto de Promoción de Exportaciones e Inversiones. Disponible en https://issuu.com/pro-ecuador/docs/ bce_mayo.

PROECUADOR. (2017). Boletín de Comercio Exterior. Instituto de Promoción de Exportaciones e Inversiones. Disponible en https://issuu.com/pro-ecuador/docs/ bce_marzo.

Scott, G., \& Adding J.. (2013). Values to Value Chains. Revista de Administração de Empresas. Rev. Adm.empres vol.54 no.1 São Paulo enero/feb. 2014, 2013, Disponible en https://doi.org/10.1590/S0034-759020140107.

SAE, Servicio de Acreditación Ecuatoriano. (2017). SAE y la Agricultura Orgánica. Obtenido de http://www. acreditacion.gob.ec/que-son-los-codigos-ciiu/.
Servicio de Información Agropecuaria F. (2008). Costos de Producción de Tomate de Árbol. (2012). Disponible en https://conectarural.org/sitio/material/costo-deproducci\%C3\%B3n-de-tomate-de-\%C3\%A1rbol-porhect $\%$ C3\%A1rea-en-antioquia.

Sukhatme, P. (1953). Teoría de encuestas por muestreo con aplicaciones, Research Gate, 1953. Disponible en https://www.researchgate.net/publication/44508938_ Teoria_de_encuestas_por_muestreo_con_ aplicaciones_Pandurang_V_Sukhatme.

Torres, A. (2012). Caracterización física, química y compuestos bioactivos de pulpa madura de tomate de árbol (Cyphomandra betacea) (Cav.) Sendtn. Revista Archivos Latinoamericanos de Nutrición vol. 62 no.4 Caracas Dic 2012, Disponible en http://www.scielo.org.ve/scielo.php?pid=S000406222012000400010\&script=sci_arttext

Zambrano, D. (2016). Cadena productiva de lácteos y su contribución al desarrollo rural del Ecuador. Estudio comparativo de la cadena láctea en el cantón Riobamba y la experiencia de Galicia (España). Santiago de Compostela: Universidad de Santiago de Compostela (USC). 